\title{
Expression of Zinc Transporter Genes in Oat (Avena sativa L.) as Influenced by Zinc-Solubilizing Bacteria
}

\section{Varsha Chaturvedi ${ }^{1,2}$, Rajeev Ranjan ${ }^{1,2}$, Manoj Chaudhary ${ }^{2}$, Shahid Ahmed ${ }^{2}$ and Krishna Kumar Dwivedi ${ }^{2} *$}

\author{
${ }^{1}$ Bundelkhand University Jhansi - 284 128, Uttar Pradesh, India \\ ${ }^{2}$ ICAR-Indian Grassland and Fodder Research Institute, \\ Jhansi - 284 003, Uttar Pradesh, India
}

*Corresponding author

\section{A B S T R A C T}

\begin{tabular}{l} 
K e y w o r d s \\
$\begin{array}{l}\text { Metal transporter, } \\
\text { Oat, Zinc } \\
\text { solubilizing } \\
\text { bacteria, Zinc } \\
\text { uptake, ZIP genes }\end{array}$ \\
\hline Article Info \\
$\begin{array}{l}\text { Accepted: } \\
\text { 22 June } 2020 \\
\text { Available Online: } \\
\text { 10 July } 2020\end{array}$ \\
\hline \hline
\end{tabular}

Mineral deficiency mostly zinc is a well-documented problem in food and forage crops affecting the crop production and subsequently the human and animal health. Oat (Avena sativa L.) is winter crop in many parts of the world and is used as multipurpose crop for grain and forage. Oat is sensitive to $\mathrm{Zn}$, which is major dry fodder and thereby causes Zn deficiency in animals. Application of Zinc solubilizing bacteria (ZSB) could be a sustainable agronomic approach to increase the soil availability of $\mathrm{Zn}$ for nutritionally rich oat. In the present study, the role of zinc solubilizing bacteria on regulation of Zn-regulated transporters (OsZIP1, OsYSL2 and OsYSL6) was assessed by quantative real-time reverse transcription PCR and semiquantative PCR, in control (without ZSB inoculation) and in treated (with ZSB inoculation) of leaf, stem and root. The expression of OsZIP1 in treated leaf and stem was more observed as compared to control whereas there is no change in root expression. The expression of OsYSL2 was more in leaf and root as compared to control. The expression of OsYSL6 was higher in treated stem and root as compared to control. These result suggested that OsZIP1, OsYSL2 and OsYSL6 in oat is an oat zinc transporters could be responsible for the Zinc transportation.

\section{Introduction}

Mineral deficiency is a well-documented problem in food and forage crops, reducing the probabilities of nutritional security. Mineral deficiency/imbalances in livestock feeds and forages have been observed in tropical and sub-tropical regions (McDowell,
1996), which often limits the performance of the animals (Corah, 1996). Several trace or inorganic elements are essential for normal growth, production and reproduction of animals that includes zinc, cobalt, copper, iodine, iron, manganese, molybdenum, selenium and perhaps chromium and fluorine, among them zinc has immense importance 
(McDowell, 1996). $\mathrm{Zn}$ is essential for normal growth, production, reproduction, health and immunity of animals and its plays role in many physio-biochemical processes. Deficiency of $\mathrm{Zn}$ reduces feed intake, growth, listlessness, excessive salivation, testicular growth, cracked hooves, fertility and skin lesions or slowed wound healing in animals (Graham et al., 2001). Zn requirement of animal is $20-75 \mathrm{mg} / \mathrm{kg}$, whereas the tolerable level of dietary zinc is suggested to be 300 to $1000 \mathrm{mg} / \mathrm{kg}$ diet but the availability of $\mathrm{Zn}$ in oat is 24-30 mg/kg (Miller et al. 1994; Ashraf $\mathrm{Y}, 1996)$.

Oat (Avena sativa L.) is an economically important crop and ranks sixth in world cereal production after wheat, rice, maize, barley and sorghum (FAO, 2012). It is an important winter forage crop in many parts of the world and is also grown as multipurpose crop for grain, pasture and forage (Ruwali et al. 2013). Differing from other cereal grains such as wheat and barley, it is rich in the antioxidants $\alpha$-tocotrienol, $\quad \alpha$ - tocopherol, and avenanthramides, as well as total dietary fibre including the soluble fibre $\beta$-glucan. Oat is the major source of dry fodder-low in $\mathrm{Zn}$ concentrations, particularly when grown on Zn-deficient soil of India (Ruwali et al., 2013). Singh et al., 2005 reported that average $\mathrm{Zn}$ content $30-32 \mathrm{mg} / \mathrm{kg}$ in Oat at different cutting stages. Ashraf, 1996 reported that average $\mathrm{Zn}$ content in different genotype of Oat is $24-30 \mathrm{mg} / \mathrm{kg}$. In recent years, with the advent of exaggerated dairy industry, the oat have fascinated the attention of breeders for its improvement due to its nutritious quality fodder for livestock and its grains as animal feed with high net energy gains (Stevens et al., 2004).

Several zinc solubilizing bacteria (ZSB) were characterized from tropical and temperate soils to provide available $\mathrm{Zn}$ (Hafeez et al., 2013). For example Bacillus and Pseudomonas from rice, wheat and soybean,
Gluconacetobacter from sugarcane capable of solubilizing $\mathrm{Zn}$ compounds into oxide, carbonate and phosphate were reported (Saravanan et al., 2011). Inoculation of these bacteria enhanced the $\mathrm{Zn}$ uptake in several crops such as rice (Vaid et al., 2014), maize (Goteti et al., 2013), wheat (Rana et al., 2012) and soybean (Sharma et al., 2012) were earlier reported. However nothing is known in oat to explore molecular mechanism of the microbe-soil-plant interactions.

Several genes are responsible for transportation and accumulation of minerals in plants. The available $\mathrm{Zn}$ from soil is taken to root membrane transport mechanisms in rice (Bashir et al 2010) and $\mathrm{Zn}$ and $\mathrm{Fe}$ regulated transporters like protein (ZIP) family (Guerinot 2000). Several reports for $\mathrm{Zn}$ uptake from soil, translocation from root to shoot as well as for storage in grains and their molecular mechanism, genes involved OsIRT1, OsIRT2, OsZIP1, OsZIP3, OsZIP4, OsZIP5, OsZIP7, and OsZIP8 were studied (Ramesh et al., 2003; Ishimaru et al., 2005; Yang et al., 2009; Lee et al., 2010). Ishimaru et al., 2005 reported that OsITR1 and OsITR2 are responsible for transport of iron from soil to root, whereas OsZIP1, OsZIP3, OsZIP4, OsZIP5, and OsZIP8 are rice plasma membrane $\mathrm{Zn}$ transporters and are induced by Zn deficiency (Ramesh et al., 2003; Ishimaru et al., 2005; Yang et al., 2009; Lee et al., 2010; Suzuki et al., 2012). Chen et al. (2008) reported the differential expression pattern of ZIP genes (OsZIP1, OsZIP3, and OsZIP4) in rice. These ZIP genes varied their expression levels at different growth stages of rice from germination to grain filling (Ishimaru et al., 2011). Krithika and Balachandar, (2016) studied the expression of Zinc transporter genes as inoculation by $\mathrm{Zn}$ solubilizing PGPR in rice. They studied the expression patterns of OsZIP1, OsZIP4, and OsZIP5 in root and shoot of rice. The study of molecular mechanism and understanding the interaction between oat plant and $\mathrm{Zn}$ solubilizing bacteria 
in terms of $\mathrm{Zn}$ transporter genes expression would help to alleviate the $\mathrm{Zn}$ deficiency as well as to improve the $\mathrm{Zn}$ fortification. In the present work, we have reported the role of zinc solubilizing bacteria on regulation of $\mathrm{Zn}$ regulated transporters (OsZIP1, OsYSL2 and OsYSL6) was assessed by quantative realtime reverse transcription PCR and semiquantative PCR, in control (without ZSB inoculation) and in treated (with ZSB inoculation) of leaf, stem and root.

\section{Materials and Methods}

\section{Plant material}

Oat (Avena sativa L.) variety JHO-822 from Indian Grassland Fodder and Research Institute, Jhansi, U.P. was used the experiment.

\section{Seed inoculation}

The seeds of oat (Avena sativa L.) variety JHO-822 were inoculated with Zinc solubilizing bacteria (ZSB) @ 200gm/10kg seed before sowing. Zinc solubilizing bacteria (ZSB) was purchased from Division of Microbiology, Indian Agricultural Research Institute, New Delhi. The required quantity of the cultures, (i.e. @ 200 gm culture per $10 \mathrm{~kg}$ seed) was mixed to $10 \%$ sugar solution to form slurry. The slurry was sprinkled on seeds and mixed with hand to make a uniform coating over the seeds. The required quantity of charcoal was added to absorb the moisture and then seeds were sown immediately (Rao and Tilak, 1977).

\section{Genomic DNA isolation and PCR amplification}

Genomic DNA was extracted from oat and rice by using CTAB method (Doyle and Doyle, 1987) with some modifications. PCR amplification were carried out in oat and rice with primer designed using the free software of Primer 3. The primer details are provided in Table 1.

\section{RNA extraction}

Total RNA from leaf, stem and root of oat was extracted separately by following the procedure of RNA Express reagent (Himedia Inc.) according to the manufacturer's instructions. Total RNA concentration was measured with a Nanodrop UV/Visible Spectrophotometer (DeNovix DS11 Spectrophotometer). The residual genomic DNA in the RNA preparation was digested with RNase-free Dnase I (Chromous Biotech Pvt. Ltd. India).

\section{Real-Time RT-PCR analysis}

Single-stranded cDNA was prepared from Total RNA by Reverse Transcription using Oligo-dT Primer. To $20 \mu \mathrm{g}$ total RNA in $30 \mu \mathrm{l}$ total volume, $2 \mu \mathrm{l}$ of the Oligo-dT Primer $(1 \mu \mathrm{g} / \mu \mathrm{l})$ was added and incubated at $65^{\circ} \mathrm{C}$ for $10 \mathrm{~min}$. After a quick chill on ice, $10 \mu 15 \mathrm{X}$ Buffer, $5 \mu 10.1 \mathrm{M}$ DTT and $2 \mu \mathrm{l} 10 \mathrm{mM}$ dNTPs were added and incubated at $42^{\circ} \mathrm{C}$ for $10 \mathrm{~min}$. Finally $1 \mu \mathrm{l}$ M-MLV RT (Chromous Biotech Pvt. Ltd. India) was added and kept at $42^{\circ} \mathrm{C}$ for1 hr. Reaction was terminated by incubation at $65{ }^{\circ} \mathrm{C}$ for $10 \mathrm{~min}$. The singlestranded cDNA prepared was used in RealTime PCR. Real Time PCR was carried out on a Realplex master cycler (Eppendrof Inc.) using the SYBR Green I dye-based detection system. The total Real Time-PCR volume of $20 \mu \mathrm{l}$ contained $10 \mu \mathrm{l} 2 \mathrm{xQ}-\mathrm{PCR}$ master mix, $150 \mathrm{ng}$ each of forward and reverse primers and $4 \mu \mathrm{l}$ of the cDNA samples as recommended by Q-PCR kit for SYBER green real time PCR (Chromous Biotech Pvt. Ltd. India). PCR was initiated with a preincubation at $95^{\circ} \mathrm{C}$ for $2 \mathrm{~min}$ followed by 40 cycles of denaturation at $95^{\circ} \mathrm{C}$ for 15 second, annealing at $55^{\circ} \mathrm{C}$ for 15 second and extension at $68^{\circ} \mathrm{C}$ for 20 second. To determine the specificity of the reaction, 
melting curve analysis was done. Data analysis of real-time PCR was carried out using mathematical model of Pfaffl (Pfaffl 2001).

\section{Semi Quantative PCR}

Semi Quantative PCR was carried out using the cDNA synthesis kit (Chromous Biotech Pvt. Ltd. India), according to the manufactures instructions.

\section{Results and Discussion}

\section{Genomic DNA isolation and PCR} amplification

Total genomic DNA was extracted from rice and oat. PCR amplification was carried out in rice as control and Oat, to check the efficiency of primers in rice and oat (Fig. 1).The amplification pattern of genes OsYSL2, Oszip1, OsYSL6 were same observed as expected size in rice and oat.

\section{Real Time PCR analysis}

RNA from control and treated oat plants were subjected for real time PCR analysis. The expression level of OsZIP1 gene was increased by 0.4 fold change in treated leaf as compared to control leaf, whereas in stem and root it was increased by 0.5 and 0.1 fold change respectively. For OsYSL2 not any significant fold changes had observed in stem whereas the expression was same in leaf and root. The fold change was much higher in root as compared to leaf and stem for Os YSL6 gene in treated as compare to control (Table 2)

\section{Semi quantitative PCR analysis}

The expression level of OsZIP1 gene in treated leaf was much higher as compared to control leaf, whereas in treated stem it was slightly increased but in root it was same as control (Fig. 2). The expression level of OsYSL2 gene in treated leaf and treated root was higher than control leaf and control root. But in treated stem there was not any change in the expression as compared to control stem (Fig. 3). The Expression level of OsYSL6 gene in treated leaf was higher as compared to control leaf, where as in treated stem it was much higher than the control stem. But in treated root it was slightly much higher as compared to control root (Fig. 4).

Table.1 Primer used for Real-Time PCR and semiquantative PCR

\begin{tabular}{|c|c|c|l|}
\hline SN & Target gene & Primer name & Sequences \\
\hline $\mathbf{1 .}$ & OsZIP1 & $\begin{array}{l}\text { OsZIP1-F } \\
\text { OsZIP1-R }\end{array}$ & $\begin{array}{l}\text { 5-CGGTTCTACACCACGGACTT-3 } \\
\text { 5-TCGAGGAACTCGACGAAGAT-3 }\end{array}$ \\
\hline $\mathbf{2 .}$ & OsYSL2 & $\begin{array}{l}\text { OsYSL2-F } \\
\text { OsYSL2-R }\end{array}$ & 5-AGAACACCGTTGTCCAGACC-3 \\
\hline $\mathbf{3 .}$ & OsYSL6 & OsYSL6-F & 5-GTTTGTCTGGGAGAGGGTGA-3 \\
\hline & & OsYSL6-R & 5-CTGGTAAGGGATGGCTTGAA-3 \\
\hline $\mathbf{4 .}$ & Tubulin & Tubulin-F & 5-TCTTCCACCCTGAGCAACTC-3 \\
\hline & & Tubulin-R & 5-GAGTTGCTCAGGGTGGAAGA-3 \\
\hline
\end{tabular}


Table.2 Expression level of target genes in different plant part of Oat

\begin{tabular}{|l|l|l|c|}
\hline $\mathbf{S N}$ & Target gene & Plant part & Fold Change (Treated/Control) \\
\hline $\mathbf{1 .}$ & OsZIP 1 & Leaf & 0.4 \\
\cline { 3 - 4 } & & Stem & 0.5 \\
\hline \multirow{2}{*}{} & & Root & 0.1 \\
\hline \multirow{2}{*}{} & OsYSL 2 & Leaf & 0.1 \\
\hline $\mathbf{3 .}$ & OsYSL 6 & Stem & 0.0 \\
\hline & & Root & 0.1 \\
\hline & & Stem & 0.2 \\
\hline & & Root & 0.4 \\
\hline
\end{tabular}

Fig.1 Amplification pattern of OsYSL2, OsZIP1 and OsYSL6 in rice and oat. M: 1Kb ladder; R1: amplified product of OsYSL2 from rice; O1: amplified product of OsYSL2 from oat; R2: amplified product of OsZIP1 from rice; O2: amplified product of OsZIP1 from oat; R3: amplified product of OsYSL6 from rice; O1: amplified product of OsYSL6 from oat

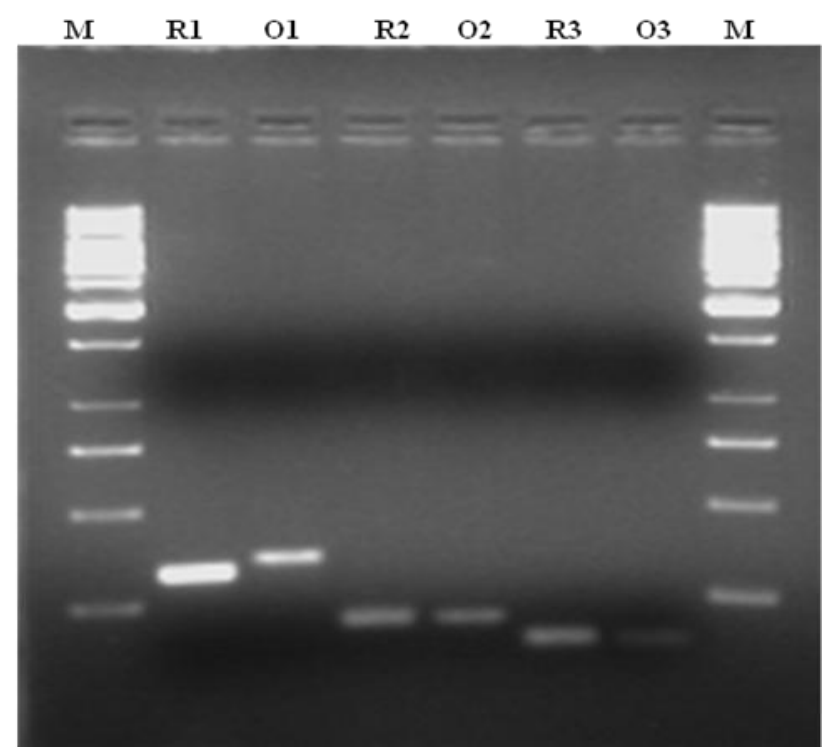


Fig.2 Semi-Quantative PCR showing expression pattern of OsZIP1 and tubulin in different plant part of oat in control and treated. CL: Control Leaf; CS: Control Stem; CR: Control Root; TL:

Treated Leaf; TS: Treated Stem; TR: Treated Root

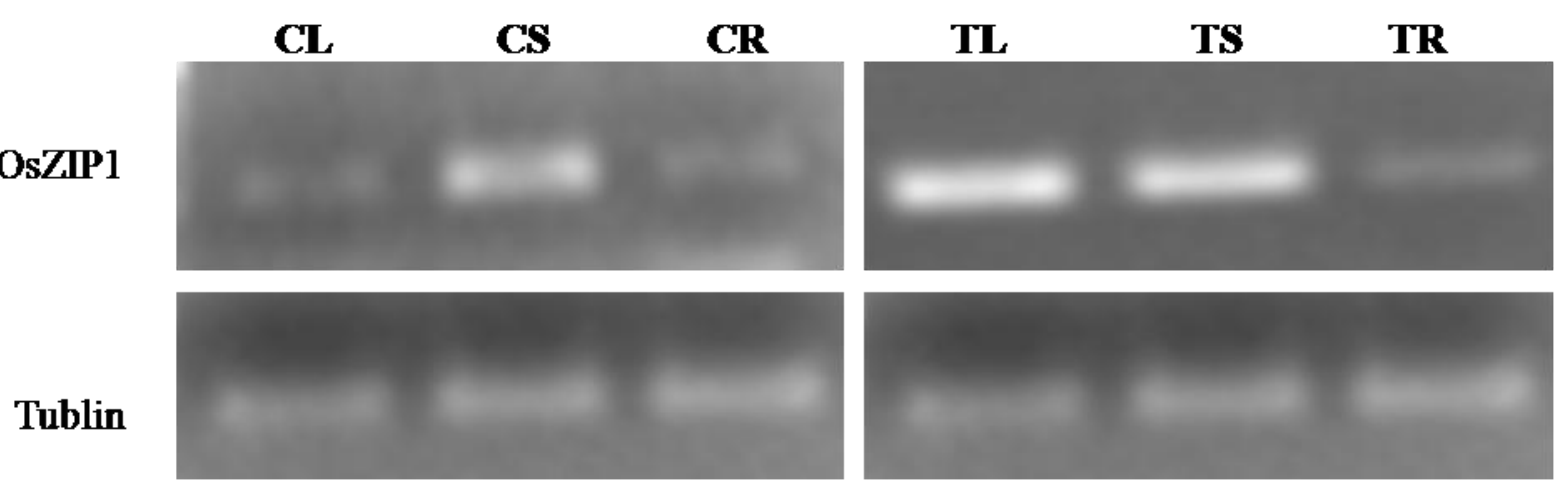

Fig.3 Semi-Quantative PCR showing expression pattern of OsYSL2 and tubulin in different plant part of oat in control and treated. CL: Control Leaf; CS: Control Stem; CR: Control Root; TL: Treated Leaf; TS: Treated Stem; TR: Treated Root

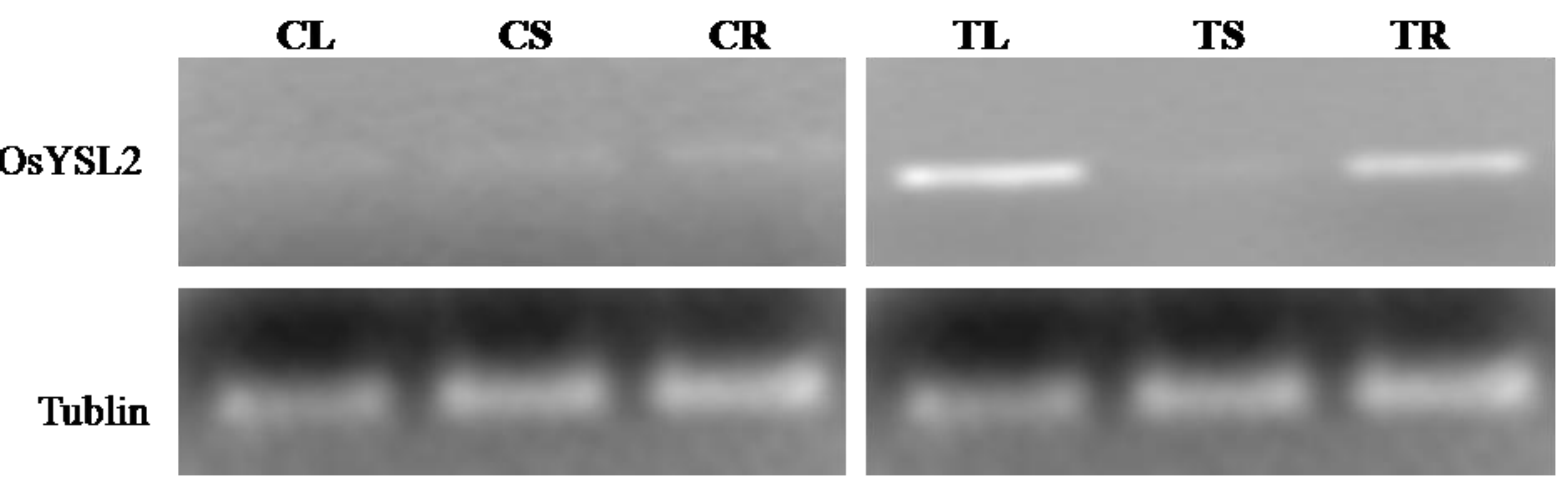

Fig.4 Semi-Quantative PCR showing expression pattern of OsYSL6 and tubulin in different plant part of oat in control and treated. CL: Control Leaf; CS: Control Stem; CR: Control Root; TL: Treated Leaf; TS: Treated Stem; TR: Treated Root

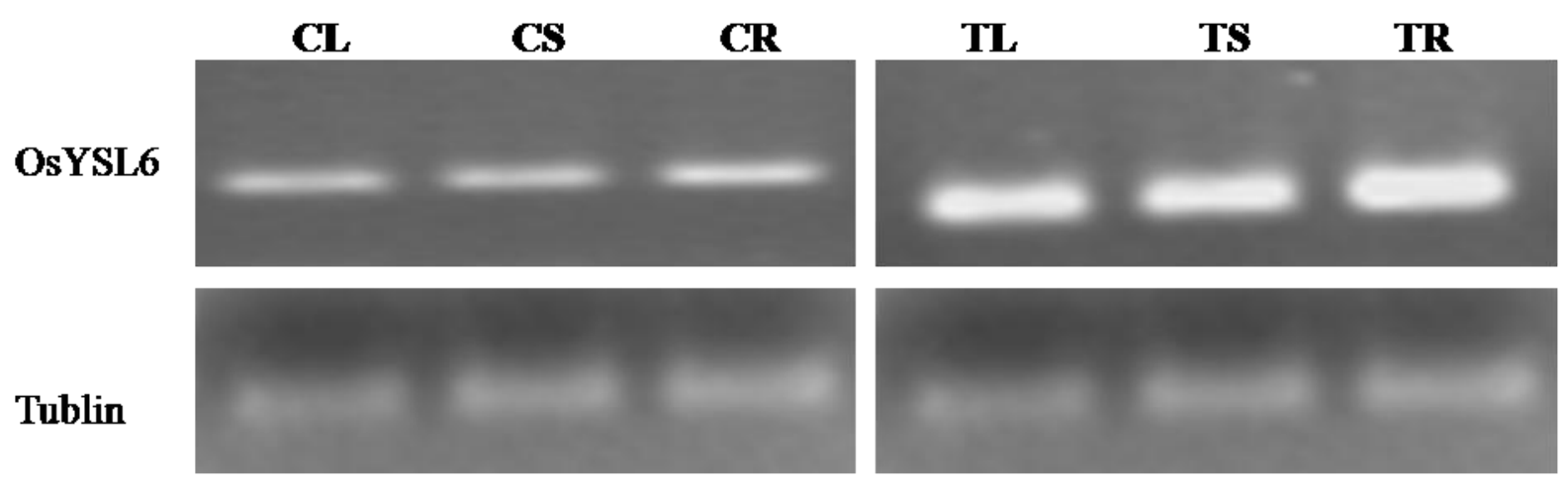


Plants evolved various mechanisms for transportation, translocation and assimilation of mineral nutrient from soil to plant. The present study framed in keeping in the view of all mechanism involved in mineral transportation, translocation and assimilation in plants. In the present study by exploiting the expression analysis of genes involved in the transportation of zinc has been studied. The molecular mechanism for the transportation of zinc is a complicated process; however the exact expression analysis study gives inside the mechanism of transportation of zinc in plant. In the present investigation transporters genes which may be responsible for the transportation of zinc were studies by their expression studies.

\section{Expression analysis of OsZIP1 gene}

The expression level of OsZIP1 gene in treated leaf was much higher as compared to control leaf, where as treated stem it was slightly increased but in root it was same as control. The ZIP family transporters are well characterized in plants (Ramesh et al., 2003). Guerinot (2000), Maser et al., (2001) suggested their involvement in uptake system for zinc. Ramesh et al., (2003); Ishimaru et al., (2005); Chen et al., (2008) demonstrated that most of ZIP family genes are induced by zinc deficiency and their expression pattern varied between root and shoot system. In our study we have observed that in control (normal soil), the expression of ZIP1 gene was less as compared to zinc treated soil (zinc efficient soil). The expression pattern varied between leaf, shoot and root system. The same result were observed by Ramesh et al., (2003); Ishimaru et al., (2005), where they showed that expression of ZIP1 gene was higher level in root than shoot under zinc deficient condition. Chen et al., (2008) also observed that OsZIP1 was up regulated in zinc deficient root, but no visible transcript in shoot of both zinc efficient and zinc inefficient rice genotype. Ramegowda et al., (2013) found that by over expressing OsZIP1 finger millet showed higher expression of this gene in leaves under zinc sufficient condition. In the present work we found that higher expression of ZIP1 in shoot than in root. This is in accordance with the earlier finding that zinc abundance reduces the OsZIP1 expression (Ramesh et al., 2003; Ishimaru et al., 2005).

\section{Expression analysis of OsYSL2 gene}

YSL2 transporter gene belong the family of YSL, they are oligopeptide transporter family (Yen et al., 2001). The expression level of OsYSL2 gene in treated leaf and treated root was higher than control leaf and control root. But in treated stem there was no change in the expression as compared to control stem. Curie et al., (2001) showed analysis of some YSL transporter family member and their involved in transport of zinc. Koike et al., (2004) showed high expression of OsYSL2 in the leaves but in root of iron deficient plant. They also demonstrate that OsYSL2 expression was induced in the leaves of iron deficient plant. Schaaf et al., (2004) reported ZmYS1 analogs of YSL2 also transported zinc and copper with iron. Curie et al., (2001) reported that iron deficiency induced opposing the expression OsYSL2 in leaves. In our study a similar pattern was observed in control, where expression was lower however; in Zinc treated soil the expression of YSL2 was much higher in leaves.

\section{Expression analysis of OsYSL6 gene}

OsYSL6 is another member of YSL family (Curie et al., 2009). The Expression level of OsYSL6 gene in treated leaf was higher as compared to control leaf, whereas in treated stem it was much higher than the control stem. But in treated root it was much higher as compared to control root. OsYSL6 was 
constitutively expressed in both leaves and root of either iron sufficient and deficient plant (Koike et al., 2004). In our study the same result were obtained in leaves, stem and root, in both the condition either $\mathrm{Zn}$ sufficient or $\mathrm{Zn}$ deficient, But the expression level was more in Zn sufficient soil.

It is concluded that the present investigation involved the study of expression of zinc transporters genes (OsZIP1, OsYSL2 and OsYSL6) through quantitative real time PCR and qualitative semi-quantitative PCR in Oat. The study involved the selection of appropriate zinc transporter genes from NCBI and their expression analysis. Three transporter genes specially OsZIP1, OsYSL2and OsYSL6 studied in control plant (without ZSB inculcation) and treated (with ZSB inculcation) in plant part such as leaf, stem and root. We proved that the inoculation of ZSB under controlled condition can able to regulate some of the $\mathrm{Zn}$-regulated transporters family genes and thereby controlled the $\mathrm{Zn}$ uptake in oat. The expressions of OsZIP1, OsYSL2 and OsYSL6 in oat were slightly higher in treated as compared to control. These results are evident that the ZSB inoculation could regulate the $\mathrm{Zn}$ uptake and translocation in oat plant.

\section{Acknowledgments}

Authors gratefully acknowledge Director, Indian Grassland and Fodder Research Institute (IGFRI), Jhansi and Indian Council of Agricultural Research (ICAR), New Delhi, India for carrying out the present investigation

\section{References}

Anonymous, 2012. Animal nutrition group, Tropical and sub-tropical countries.

Ashraf, Y., 1996. Ph.D. Dissertation, Lahore Pakistan.
Bashir, K., Ishimaru, Y., \& Nishizawa, N. K. 2010. Iron uptake and loading into rice grains. Rice. 3(2-3): 122-130.

Chen, W. R., Feng, Y., \& Chao, Y. E. 2008. Genomic analysis and expression pattern of OsZIP1, OsZIP3, and OsZIP4 in two rice (Oryza sativa L.) genotypes with different zinc efficiency. Russian Journal of Plant Physiology. 55(3): 400409.

Corah, L. 1996. Trace mineral requirements of grazing cattle. Animal Feed Science and Technology. 59: 61-70.

Curie, C., Cassin, G., Couch, D. 2009. Metal movement within the plant: contribution of nicotianamine and yellow stripe 1like transporters. Annals of Botany. 103(1): 1-11.

Curie, C., Panaviene, Z., Loulergue, C., Dellaporta, S. L., Briat, J. F., \& Walker, E. L. 2001. Maize yellow stripe1 encodes a membrane protein directly involved in $\mathrm{Fe}$ (III) uptake. Nature. 409(6818): 346.

Doyle, J. J., Doyle, J. L. 1987. A rapid DNA isolation procedure for small quantities of fresh leaf tissue. Phytochemical Bulletin. V.19, pp.11-15.

Goteti, P. K., Emmanuel, L. D. A., Desai, S., Shaik, M. H. A. 2013. Prospective zinc solubilising bacteria for enhanced nutrient uptake and growth promotion in maize (Zea mays L.). Int. J. Microbiol. 2013:869697 10.1155/2013/869697.

Graham, R. D., Welch, R. M., and Bouis, H. E. 2001. Addressing micronutrient malnutrition through enhancing the nutritional quality of staple foods: principles, perspectives and knowledge gaps. Adv. Agron. 70: 77-142

Guerinot, M. L. 2000. The ZIP family of metal transporters. Biochimica et Biophysica Acta (BBA)Biomembranes. 1465(1-2): 190-198.

Hafeez, F. Y., Abaid-Ullah, M., \& Hassan, M. 
N. 2013. Plant growth-promoting rhizobacteria as zinc mobilizers: a promising approach for cereals biofortification. In Bacteria in Agrobiology: Crop Productivity. Springer, Berlin, Heidelberg. pp. 217 235.

Ishimaru, Y., Bashir K., Nishizawa, N. 2011. $\mathrm{Zn}$ uptake and translocation in rice plants. Rice. 4: 21-27.

Ishimaru, Y., Suzuki, M., Kobayashi, T., Takahashi, M., Nakanishi, H., Mori, S., \& Nishizawa, N. K. 2005. OsZIP4, a novel zinc-regulated zinc transporter in rice. Journal of Experimental Botany. 56(422): 3207-3214.

Koike, S., Inoue, H., Mizuno, D., Takahashi, M., Nakanishi, H., Mori, S., \& Nishizawa, N. K. 2004. OsYSL2 is a rice metal- nicotianamine transporter that is regulated by iron and expressed in the phloem. The Plant Journal. 39(3): 415-424.

Krithika, S. and Balachandar, D. 2016. Expression of Zinc Transporter Genes in Rice as Influenced by ZincSolubilizing Enterobacter cloacae Strain ZSB14. Front. Plant Sci. 7: 446.

Lee, S., Jeong, H. J., Kim, S. A., Lee, J., Guerinot, M. L., \& An, G. 2010. OsZIP5 is a plasma membrane zinc transporter in rice. Plant molecular biology. 73(4-5): 507-517.

Maser, P., Sébastien Thomine, Julian I. Schroeder, John M. Ward, Kendal Hirschi, Heven Sze, Ina N. Talke, Anna Amtmann, Frans J.M. Maathuis, Dale Sanders, Jeff F. Harper, Jason Tchieu, Michael Gribskov, Michael W. Persans, David E. Salt, Sun A Kim, Mary Lou Guerinot. 2001. Phylogenetic relationships within cation transporter families of Arabidopsis. Plant Physiol. 126: 1646-1667.

McDowell, L. R. 1996. Feeding minerals to cattle on pasture. Animal Feed Science and Technology. 60(3-4): 247-271.

Miller, R.O., Jacobsen, J.S. and Skogley, E.O. 1994. Aerial accumulation and partitioning of nutrients by hard red spring wheat. Communications in Soil Science Plant Analysis. 25(11): 18911911.

Pfaffl, M. W. 2001. A new mathematical model for relative quantification in realtime RT-PCR. Nucleic acids research. 29(9): e45-e45.

Ramegowda, Y., Venkategowda, R., Jagadish, P., Govind, G., Hanumanthareddy, R. R., Makarla, U., \& Guligowda, S. A. 2013. Expression of a rice $\mathrm{Zn}$ transporter, OsZIP1, increases $\mathrm{Zn}$ concentration in tobacco and finger millet transgenic plants. Plant biotechnology reports. 7(3): 309-319.

Ramesh, S. A., Shin, R., Eide, D. J., and Schachtman, D. P. 2003. Differential metal selectivity and gene expression of two zinc transporters from rice. Plant Physiology. 133(1): 126-134.

Rana, A., Saharan, B., Nain, L., Prasanna, R., Shivay ,Y. S. 2012. Enhancing micronutrient uptake and yield of wheat through bacterial PGPR consortia. Soil Sci. Plant Nutr. 58: 573-582.

Rao, S.N.S. and Tilak, K.V.B.R., 1977, Rhizobial culture - their role in pulse production.Souvenir

Bulletin. Directorate of Pulse Development, Govt. of India, Lucknow, pp. 31-34.

Ruwali, Y., Kumar, L. and Verma, J. S. 2013. Screening for resistance to crown rust in oat genotypes through morphological and molecular parameters. Journal Plant Pathology and Microbiology. 4(10): 13.

Saravanan, V. S., Kumar, M. R., \& Sa, T. M. 2011. Microbial zinc solubilization and their role on plants. In Bacteria in Agrobiology: Plant Nutrient Management Springer, Berlin, pp. 4763. 
Schaaf, G., Ludewig, U., Erenoglu, B. E., Mori, S., Kitahara, T., \& von Wirén, N. 2004. ZmYS1 functions as a protoncoupled symporter for phytosiderophore-and nicotianaminechelated metals. Journal of Biological Chemistry. 279(10): 9091-9096.

Sharma, S. K., Sharma, M. P., Ramesh, A., Joshi, O. P. 2012. Characterization of zinc-solubilizing Bacillus isolates and their potential to influence zinc assimilation in soybean seeds. J. Microbiol. Biotechnol. 22: 352-359.

Singh, K. K., Nag, S. K., Garg, M. R., and Mojumdar, A. B. 2005. Mineral status of some commonly used feeds and forages vis-à-vis requirements. Animal Nutrition and Feed Technology. 5: 171177.

Stevens, E. J., Armstrong, K. W., Bezar, H. J., Griffin, W. B., \& Hampton, J. G. 2004. Fodder oats an overview. Fodder oats: A world overview. (33): 11-18.
Suzuki, M., Bashir, K., Inoue, H., Takahashi, M., Nakanishi, H., Nishizawa, N. 2012. Accumulation of starch in Zn-deficient rice. Rice (5): 1-8.

Vaid, S. K., Kumar, B., Sharma, A., Shukla, A. K., \& Srivastava, P. C. 2014. Effect of $\mathrm{Zn}$ solubilizing bacteria on growth promotion and $\mathrm{Zn}$ nutrition of rice. Journal of soil science and plant nutrition. 14(4): 889-910.

Yang, X., Huang, J., Jiang, Y., \& Zhang, H. S. 2009. Cloning and functional identification of two members of the ZIP (Zrt, Irt-like protein) gene family in rice (Oryza sativa L.). Molecular biology reports. 36(2): 281-287.

Yen, M. R., Tseng, Y. H., Saier, M. H. Jr. 2001. Maize Yellow Stripe1, an ironphytosiderophore uptake transporter, is a member of the oligopeptide transporter (OPT) family. Microbiology. 147: 2881-2883.

\section{How to cite this article:}

Varsha Chaturvedi, Rajeev Ranjan, Manoj Chaudhary, Shahid Ahmed and Krishna Kumar Dwivedi. 2020. Expression of Zinc Transporter Genes in Oat (Avena sativa L.) as Influenced by Zinc-Solubilizing Bacteria. Int.J.Curr.Microbiol.App.Sci. 9(07): 3448-3457. doi: https://doi.org/10.20546/ijcmas.2020.907.403 